\title{
Use of Soybean as Partial Substitute of Fish Meal in the Diets of Rohu, Labeo rohita (Ham.) fry
}

\author{
D. A. Jahan ${ }^{1 *}$, L. Hussain ${ }^{2}$, M. A. Islam², M. M. Khan ${ }^{1}$ and A. Nima ${ }^{3}$ \\ ${ }^{I}$ Bangladesh Fisheries Research Institute, Freshwater Station, Mymensingh-2201, Bangladesh \\ ${ }^{2}$ Dept. of Fisheries Biology and Genetics, Bangladesh Agricultural University, Mymensingh-2202 \\ ${ }^{3}$ Bangladesh Fisheries Research Institute, Riverine Station, Chandpur-3602, Bangladesh \\ *Corresponding author and E-mail: durin_bfri@yahoo.com
}

Received: 27 April 2012

Accepted: 15 November 2012

\begin{abstract}
A 60-day feeding trial was conducted in a static indoor rearing system in 12 glass aquaria to investigate the possibility of using soybean meal protein in lieu of fishmeal as dietary protein source for Labeo rohita fry. Four iso-nitrogenous (30\% protein) and iso-caloric (19 kJ/g GE) experimental diets were prepared as: diet 1 (100\% fishmeal protein), diet $2(75 \%$ fishmeal protein $+25 \%$ soybean meal protein), diet 3 (50\% fishmeal protein $+50 \%$ soybean meal protein) and diet 4 (25\% fishmeal protein $+75 \%$ soybean meal protein) and were fed to triplicate groups of 10 fish (per aquarium). Fish were fed two times daily at a rate of $5 \%$ of their body weight during the entire experimental period. The feeding ration was adjusted every $10^{\text {th }}$ day through sampling of fish. Growth rate, feed conversion ratio $(\mathrm{FCR})$ and protein efficiency ratio $(\mathrm{PER})$ were significantly higher $(\mathrm{P}<0.05)$ in fish fed with diet 2 , but those were similar to the diets 1 and 3. Analysis of proximate composition of the whole fish fed with different diets did not show any significant difference $(\mathrm{P}>0.05)$. The growth rates, FCR and PER as obtained from the different treatments indicate that fishmeal protein could be replaced up to $50 \%$ by soybean meal protein in the diet of $L$. rohita fry without supplementation of amino acids.
\end{abstract}

\section{Keywords: Rohu (Labeo rohita), fishmeal, soybean meal, growth, feed utilisation}

\section{Introduction}

Fish meal is one of the most expensive ingredients in prepared fish diets and its availability as well as price fluctuations are threatening the aquaculture industry. The scarcity of good quality fishmeal and escalating prices thereof have generated renewed interest to use less expensive plant protein sources to partially replace fishmeal is a major research priority (Tacon, 1993). Among all protein rich plant feed stuffs, soybean meal protein has one of the best amino acid profiles to meet the high protein requirement and provides an added advantage in feed formulations because of it's essential amino acid contents. The amino acid profile of soya protein is generally superior to those of the other plant proteins (O'keefe, 2003).

The efficiency of various plant protein sources for partial and complete replacement of fishmeal in aquafeeds has been investigated by a number of researchers (Saha and Ray, 1998; El-Sayed, 1999; Hasanuzzaman et al., 2009). It is revealed that plant feedstuffs with high protein content are preferentially used in formulating diets for most species of fish. The amount of plant protein used in fish diets depends on the species, availability, costs, acceptability by fish, nutrient content and availability and presence of toxins or anti- 
nutritional factors (Lim and Dominy, 1991). The need for diet developing program using locally available ingredients such as soybean for carp culture in this region has been frequently stressed. It might be due to the fear of antinutritional factors of soybean, but it has been reported that roasted soybean is free from tripsin inhibitor (Priyadarshini et al., 2011). Thus, it is necessary to evaluate the nutritional efficacy of soybean meal in the diets of carps in control condition. The present study was therefore undertaken to evaluate the suitability of commercially available soybean meal as a partial substitute for fishmeal, with a view to use it as one of the potential dietary ingredients for developing a cost effective supplemental feed for the fingerlings of an Indian major carp, L. rohita.

\section{Materials and Methods}

The feeding trial was conducted in the Department of Fisheries Biology and Genetics, Bangladesh Agricultural University, Mymensingh for 60 days during August and September, 2004.

\subsection{Experimental diets}

Four iso-nitrogenous and iso-caloric $(19 \mathrm{~kJ} / \mathrm{g}$ GE) experimental diets viz. diet $1 \quad(100 \%$ fishmeal protein), diet 2 (75\% fishmeal protein + $25 \%$ soybean meal protein), diet $3(50 \%$ fishmeal protein $+50 \%$ soybean meal protein) and diet 4 (25\% fishmeal protein $+75 \%$ soybean meal protein) were prepared to contain $30 \%$ protein and $11 \%$ lipid without amino acid supplementation. Diet 1 was used as a control. Fishmeal (Malaysia origin) and roasted soybean flour (Bangladesh origin) were used as the main sources of protein. Dextrin (starch) was used as the source of carbohydrate and carboxy-methylcellulose (CMC) was used as binder. Diets were referred to by two numbers separated by a ' $\%$, the first and second number being percent of fishmeal protein and soybean meal protein, respectively. Formulation and proximate composition of the experimental diets are shown in Table 1.
All dry ingredients were ground finely and sieved. After sieving, all the required amounts of dry ingredients along with the vitamin premix were weighed as per formula (Table 1) of the experimental diets. Proximate composition of diet ingredients and formulated diets were analyzed following AOAC (1990) methods. After thorough mixing of the major ingredients, soybean oil was gradually added to the dry feed. Enough water was added to make it a stiff dough. The mixture was passed through a handpelleting machine to obtain pellets using $3 \mathrm{~mm}$ die and pellets were dried in an oven at $40{ }^{\circ} \mathrm{C}$ for 24 hours. The pellets were then crushed and sieved to obtain the particle size of $500 \mu \mathrm{m}$. All the diets were packed separately in airtight plastic bags and were labelled and stored in a deep freeze.

\subsection{Experimental system and animals}

The experiment was conducted in a static indoor rearing system consisted of a series of glass aquaria. Twelve glass aquaria $(44 \times 24 \times 24$ $\mathrm{cm}^{3}$ ) each having $25 \mathrm{~L}$ capacity were used for the growth trial. The source of water was deep tubewell. Continuous artificial aeration was provided to maintain an adequate level of dissolved oxygen in water of all the glass aquaria. Natural photoperiod of $12 \mathrm{~h}$ light and $12 \mathrm{~h}$ dark was maintained throughout the experiment. Water quality parameters such as $\mathrm{pH}$, ammonia, nitrate and nitrite were maintained within acceptable ranges for rohu through uneaten feed and faeces removal, regular partial water change and proper care. Twenty days old (average weight $0.86 \pm$ $0.03 \mathrm{~g})$ L. rohita fry were collected from Bangladesh Fisheries Research Institute and acclimatized to the laboratory conditions and fed with a mixture of rice bran and mustard oil cake (1:1) for 7 days prior to commencement of the experiment.

\subsection{Experimental procedure}

The experimental fish, L. rohita fry $(0.86 \pm 0.03$ g) were randomly assigned into groups of 10 per 25-L capacity glass aquarea. Each dietary 
treatment had three replications and the experiment was conducted for 60 days. The fish were individually weighed at the beginning and at the end of the experiment. Fish were fed the experimental diets two times daily at 09:00 and 15:00 $\mathrm{h}$ at a fixed feeding rate of $5 \%$ body weight during the entire experimental period. The feeding quantity was readjusted at every $10^{\text {th }}$ day on the basis of actual average weight of the fish. Uneaten feed was removed by siphoning $1 \mathrm{~h}$ after each feeding. Water in each aquarium was partially replaced twice daily during the removal of uneaten feed or faeces. At the onset of the experiment, from the lots of collected fish, 10 fish were analyzed for initial carcass composition. At the termination of the experiment, all fishes were weighed individually and nine fish were taken from each replication for determination of whole body composition and histological study of the liver.

Table 1. Formulation and proximate composition of the experimental diets (\% dry matter basis)

\begin{tabular}{|c|c|c|c|c|}
\hline \multirow{2}{*}{$\begin{array}{l}\text { Diet No.: } \\
\text { (Fish meal / Soybean meal) } \%\end{array}$} & \multicolumn{4}{|c|}{ Diets number } \\
\hline & $\begin{array}{c}1 \\
\text { (Control) }(100 / 0)\end{array}$ & $\begin{array}{c}\mathbf{2} \\
(75 / 25)\end{array}$ & $\begin{array}{c}\mathbf{3} \\
(50 / 50) \\
\end{array}$ & $\begin{array}{c}\mathbf{4} \\
(25 / 75)\end{array}$ \\
\hline \multicolumn{5}{|l|}{ Ingredients: } \\
\hline Fish meal $^{1 \mathrm{a}}$ & 50.84 & 38.13 & 25.42 & 12.71 \\
\hline $\begin{array}{l}\text { Soybean meal (Dehulled, solvent } \\
\text { extract) }^{2 \mathrm{~b}}\end{array}$ & 0.00 & 17.32 & 34.64 & 51.96 \\
\hline Soybean oil ${ }^{\mathrm{c}}$ & 2.70 & 01.0 & 01.0 & - \\
\hline Dextrin (starch) ${ }^{\mathrm{d}}$ & 41.46 & 38.55 & 33.94 & 30.33 \\
\hline $\begin{array}{l}\text { Carboxymethyl cellulose } \\
\text { (Binder) }^{\text {3d }}\end{array}$ & 3.00 & 3.00 & 3.00 & 3.00 \\
\hline Vitamin premix ${ }^{a}$ & 1.00 & 1.00 & 1.00 & 1.00 \\
\hline Mineral premix ${ }^{a}$ & 1.00 & 1.00 & 1.00 & 1.00 \\
\hline \multicolumn{5}{|l|}{ Proximate composition: } \\
\hline Crude Protein & 30.43 & 30.36 & 29.81 & 30.06 \\
\hline Crude Fat / Lipid & 11.01 & 11.00 & 10.56 & 10.76 \\
\hline Ash & 11.50 & 9.95 & 8.20 & 6.11 \\
\hline Fibre & 2.20 & 2.35 & 2.40 & 2.52 \\
\hline $\mathrm{NFE}^{4}$ & 44.86 & 46.34 & 49.03 & 50.55 \\
\hline $\mathrm{GE}(\mathrm{kJ} / \mathrm{g})^{5}$ & 18.90 & 19.14 & 19.31 & 19.40 \\
\hline P / GE ratio ${ }^{6}$ & 16.09 & 15.86 & 15.44 & 15.25 \\
\hline
\end{tabular}

${ }^{1}$ Crude protein: $59.50 \%$; Crude fat: $14.37 \%$; Fibre: $1.06 \%$; Ash: $22.37 \%$, NFE: $1.70 \%$

${ }^{2}$ Crude protein: $43.30 \%$; Crude fat: $15.55 \%$; Fibre: $4.95 \%$; Ash: $5.71 \%$, NFE: $30.49 \%$

${ }^{3}$ Carboxymethyl cellulose - Sodium salt, high viscosity

${ }^{4} \mathrm{NFE}=$ Nitrogen free extractives, calculated as $100-(\%$ protein $+\%$ Lipid $+\%$ Ash $+\%$ Fibre $)$

${ }^{5} \mathrm{GE}=$ Gross energy content

${ }^{6} \mathrm{P} / \mathrm{GE}$ ratio $=$ Protein to energy ratio in $\mathrm{mg}$ protein $\mathrm{kJ}^{-1} \mathrm{GE}$

${ }^{a}$ Malaysia origin

${ }^{\mathrm{b}}$ Bangladesh origin

c Teer brand, Bangladesh

${ }^{\mathrm{d}}$ Merck, India 


\subsection{Histological studies}

After termination of the experiment, livers from nine fish from each treatment were fixed in $10 \%$ neutral buffered formalin. Samples were stained with hematoxylin and eosin and periodic acidSchiff (PAS) for histological examination following the procedures described by Humason (1979).

\subsection{Analytical methods and analysis of data}

Whole fish body were analyzed following AOAC (1990) methods. Water quality parameters were analyzed according to APHA (1980). Specific growth rate (SGR), \% weight gain, food conversion ratio (FCR), protein efficiency ratio (PER) and apparent net protein utilization (ANPU) were calculated as:

SGR $(\% /$ day $)=\{($ Ln. Final body weight - Ln. Initial body weight) / days $\} \times 100$

$\%$ Weight gain $=($ Final body weight - Initial body weight / Initial body weight) $\times 100$

FCR $=$ Food fed ( $g$ dry weight $) /$ Live weight gained $(\mathrm{g})$

PER = Live weight gain $(\mathrm{g}) /$ Crude protein fed (g dry weight)

ANPU $(\%)=\{($ Final carcass protein-Initial carcass protein)/Total dry protein consumed $\} \times 100$

Data were subjected to one-way analysis of variance (ANOVA) followed by Duncan's multiple range tests to test the difference between treatment means. Standard deviation $( \pm$ SD) was calculated to identify the range of means.

\section{Results and Discussion}

Neither mortality nor external clinical symptoms was observed in any treatment during the entire period of the experiment. Growth responses and feed utilization of the experimental diets are shown in Table 2 . The $10^{\text {th }}$ day growth response is shown in Fig. 1. The gradual increase in average final weight of fish with time indicates that the fish belonging to different dietary groups fed actively. However, the gain in fish body weight, average live weight gain and SGR as recorded from diet 2 were the highest $(\mathrm{P}<0.05)$, while those of diet 4 were the lowest $(\mathrm{P}>0.05)$. No significant differences $(\mathrm{P}>0.05)$ in weight gain were observed between diets 1 and 3 (Table 2 ). The feed conversion ratio (FCR) was also the highest (3.14) in case of diet 4. The lowest FCR and the highest protein efficiency ratio (PER), apparent net protein utilization (ANPU) were obtained with diet 2 and were significantly different $(\mathrm{P}<0.05)$ from those of all other dietary groups. However, the PER and ANPU in diet 1 and diet 3 were similar (Table 2). Relatively good (lower) FCR was obtained by Devi et al. (1999) in case of $L$. rohita fingerlings fed with diet including $20 \%$ commercially available soybean meal, while feeding with $40 \%$ and $60 \%$ soybean meal diet significantly depressed the performance (higher FCR). Akhteruzzaman (1999) reported that $100 \%$ replacement of fishmeal by soybean meal for $L$. rohita showed lower performance than $100 \%$ fishmeal. He also reported that $50 \%$ fishmeal protein replaced by soybean meal protein gave an excellent weight gain in carp fry, L. rohita in comparison with $100 \%$ fishmeal based diet. Shiau et al. (1990) also observed that defatted or full fat soybean meal could be used to replace $30 \%$ fishmeal protein in a diet for tilapia.

Results of the present study demonstrated unhindered growth of $L$. rohita fry fed on soybean meal without supplementation of amino acids except fishes under diet 4. Although, the inclusion of soybean meal up to $50 \%$ in the diet resulted in the growth performance of L. rohita fry comparable to that of the control, where $100 \%$ fishmeal was used. However, with the replacement of $25 \%$ fish protein by soybean protein, the growth performance of $L$. rohita fry was excellent (Table 2). Shiau et al. (1989) observed that tilapia diet in which $100 \%$ fishmeal was replaced by soybean meal either with or without supplementation of methionine 
showed significantly lower weight gain, feed conversion ratio, protein efficiency ratio and protein digestibility than that of the group fed with diets containing fishmeal as the main source of protein. Akiyama (1989) reported that energy, phosphorus and methionine levels must be considered when utilizing high level of soybean meal in fish feeds. Nose (1979) reported that the amino acid composition of soybean meal indicates that soybean meal is deficient in methionine when compared to the amino acid requirement of common carp fingerlings. Moreover, Viola et al. (1982) reported that soybean meal is deficient in available energy and lysine as well as methionine for carp (Cyprinus carpio). Reduction in growth of $L$. rohita fry with diet 4 (highest soybean meal protein) in our study might be caused by an imbalance of amino acids which was covered by fishmeal protein in other diets.

The whole body compositions of the experimental fish are shown in Table 3. It was observed that protein and fat contents increased while moisture and ash contents decreased at the end of the feeding trials in all the treatments in comparison with the corresponding initial values. Whole body composition at the end of the feeding trial resulted in no significant difference
$(\mathrm{P}>0.05)$ in respect of percentage moisture, protein, fat and ash among the fish fed with the experimental diets. All diets were formulated to be similar in protein and energy content. The non-significant difference in body composition of fishes might be due to higher level of inclusion of plant protein sources that do not affect any significant difference in fish body. Khan et al. (2012) reported that incorporation of plant protein by replacing fishmeal did not have a significant effect on the whole body composition of Indian major carps, Catla catla, Labeo rohita and Cirrhinus mrigala. Similarly, Pongmaneerat and Watanabe (1993) reported use of soybean meal as the sole protein source, the body protein content of carps was not greatly influenced.

Histological studies of liver of the fish samples belonging to different treatments were compared with those of the control group, which did not show any alteration from normal histology (Fig. $2)$. Slight irregularly arranged hepatocytes and some glycogen deposition were observed in the liver of fish fed with $50 \%$ soybean meal in the diet (Fig. 3). When the level of soybean meal was used up to $75 \%$ in the diets, necrotic hepatocytes with huge empty spaces and some glycogen was present (Fig. 4).

Table 2. Growth performance, feed and protein efficiency of Labeo rohita fry fed on experimental diets for 60 days

\begin{tabular}{lcccc}
\hline Diet No.: & \multicolumn{4}{c}{ Diets Number } \\
(Fish meal / Soybean meal) $\%$ & $\mathbf{1}($ Control) & $\mathbf{2}$ & $\mathbf{3}$ & $\mathbf{4}$ \\
Parameters: & $(100 / 0)$ & $(75 / 25)$ & $(50 / 50)$ & $(25 / 75)$ \\
\hline Initial body wt. (g) & $0.86 \pm 0.03$ & $0.86 \pm 0.04$ & $0.86 \pm 0.05$ & $0.85 \pm 0.05$ \\
Final body wt. (g) & $2.63^{\mathrm{b}} \pm 0.06$ & $2.97^{\mathrm{a}} \pm 0.07$ & $2.58^{\mathrm{b}} \pm 0.05$ & $2.02^{\mathrm{c}} \pm 0.08$ \\
Percent wt. gain (\%) & $206^{\mathrm{b}} \pm 7.27$ & $245^{\mathrm{a}} \pm 7.63$ & $200^{\mathrm{b}} \pm 6.16$ & $135^{\mathrm{c}} \pm 8.78$ \\
Specific growth rate (SGR) & $1.87^{\mathrm{b}} \pm 0.04$ & $2.07^{\mathrm{a}} \pm 0.04$ & $1.83^{\mathrm{b}} \pm 0.04$ & $1.43^{\mathrm{c}} \pm 0.06$ \\
(\% day) & $2.29^{\mathrm{b}} \pm 0.14$ & $2.02^{\mathrm{c}} \pm 0.03$ & $2.30^{\mathrm{b}} \pm 0.09$ & $3.14^{\mathrm{a}} \pm 0.11$ \\
Feed conversion ratio (FCR) & $1.40^{\mathrm{b}} \pm 0.18$ & $1.65^{\mathrm{a}} \pm 0.02$ & $1.45^{\mathrm{b}} \pm 0.06$ & $1.06^{\mathrm{c}} \pm 0.04$ \\
Protein efficiency ratio (PER) & $21.03^{\mathrm{b}} \pm 1.65$ & $24.49^{\mathrm{a}} \pm 2.00$ & $21.13^{\mathrm{b}} \pm 2.00$ & $16.10^{\mathrm{c}} \pm 0.45$ \\
Apparent net protein & 100 & 100 & 100 & 100 \\
utilisation ( ANPU, \%) & & & 100 \\
Survival rate (\%) & & &
\end{tabular}

NB: Values are means \pm SD of three replications. Figures in the same row having different superscripts are significantly different $(\mathrm{P}<0.05)$. 


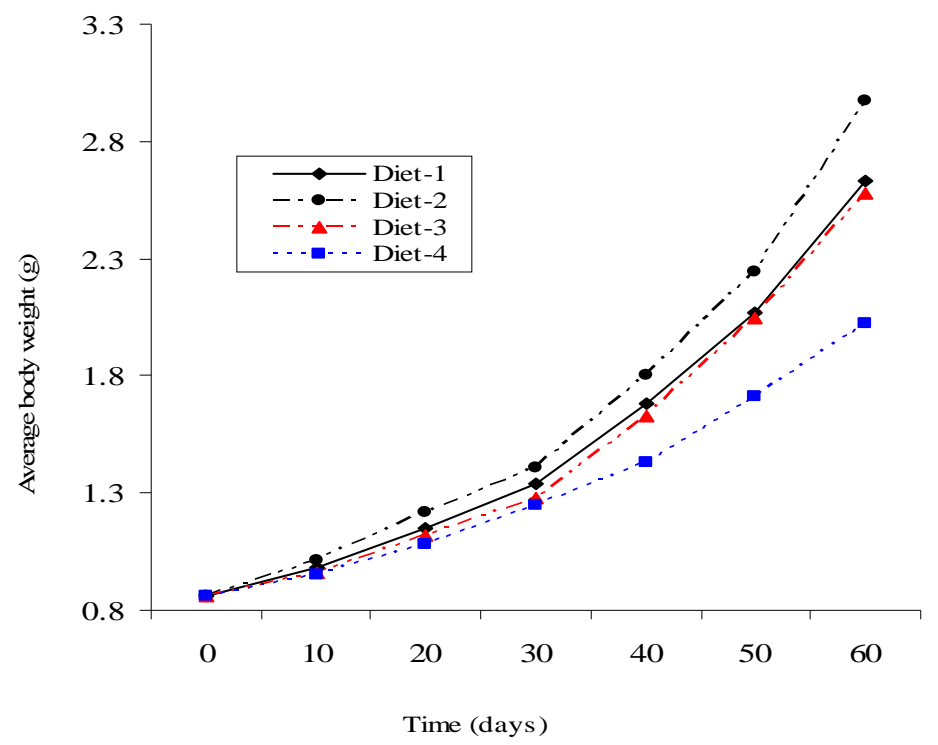

Fig. 1. The mean $10^{\text {th }}$ day growth increment of rohu, Labeo rohita fry fed on four experimental diets for 60 days

Table 3. Whole body composition (\% wet weight basis) of L. rohita fry at the beginning start and at the end of the experiment

\begin{tabular}{|c|c|c|c|c|c|c|c|}
\hline \multirow{2}{*}{$\begin{array}{l}\text { Diet No.: } \\
\text { (Fish meal/Soy } \\
\text { meal) \% } \\
\text { Components: }\end{array}$} & \multirow[b]{2}{*}{ Initial } & \multicolumn{4}{|c|}{ Diets Number } & \multirow{2}{*}{$\begin{array}{c}\mathrm{F} \\
\text { value }\end{array}$} & \multirow[b]{2}{*}{$\pm \mathrm{SE}$} \\
\hline & & $\begin{array}{c}\mathbf{1} \\
(100 / 0) \\
\end{array}$ & $\begin{array}{c}\mathbf{2} \\
(75 / 25) \\
\end{array}$ & $\begin{array}{c}\mathbf{3} \\
(50 / 50) \\
\end{array}$ & $\begin{array}{c}\mathbf{4} \\
(25 / 75) \\
\end{array}$ & & \\
\hline Moisture & $80.25 \pm 0.76$ & $75.68 \pm 0.98$ & $74.22 \pm 0.69$ & $75.16 \pm 0.88$ & $74.91 \pm 0.68$ & $0.73^{\mathrm{NS}}$ & 0.23 \\
\hline Crude protein & $11.86 \pm 0.38$ & $13.67 \pm 0.47$ & $13.97 \pm 0.75$ & $13.65 \pm 0.59$ & $13.70 \pm 0.35$ & $0.21^{\mathrm{NS}}$ & 0.14 \\
\hline Crude lipid & $2.21 \pm 0.26$ & $4.54 \pm 0.48$ & $4.81 \pm 0.38$ & $4.44 \pm 0.42$ & $4.43 \pm 0.27$ & $0.60^{\mathrm{NS}}$ & 0.11 \\
\hline Ash & $1.75 \pm 0.18$ & $2.58 \pm 0.13$ & $2.42 \pm 0.29$ & $2.36 \pm 0.27$ & $2.34 \pm 0.10$ & $0.78^{\mathrm{NS}}$ & 0.06 \\
\hline
\end{tabular}

NB: Values are means \pm SD of three replications. NS $=$ Non significant

The findings indicated that irregular arranged hepatocytes started with $50 \%$ inclusion of soya based protein which turned necrotic hepatocytes with the use of higher (75\%) soya protein. However, the liver histology of fish fed $25 \%$ soybean meal in the diet was similar to the control (Fig. 5). Robaina et al. (1995) reported that areas with high levels of hepatocytes vacuolization and disorganization were present in some samples when fish was fed with $30 \%$ soybean meal diet, while Hossain and Jaunecy (1989) observed histological abnormalities in liver tissues of common carp fed with $50 \%$ mustard protein. 


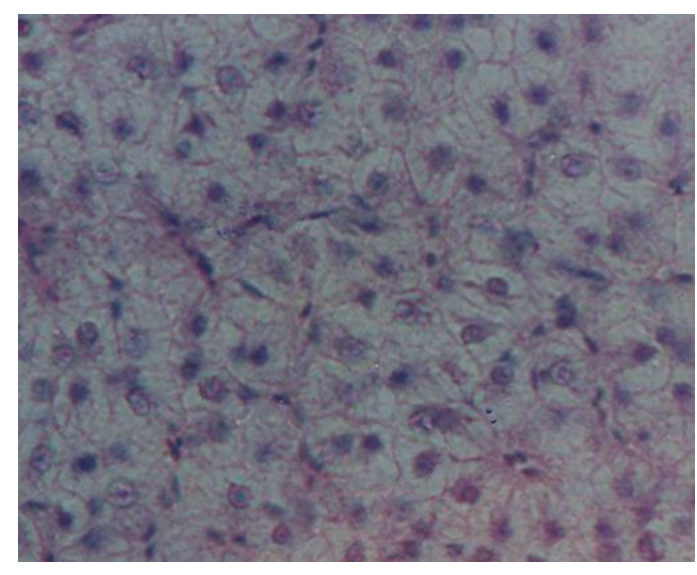

Fig. 2. Section of liver of $L$. rohita from treatment 1. Normally arranged hepatocytes with no glycogen and intercellular fat deposition (H\&Ex420).

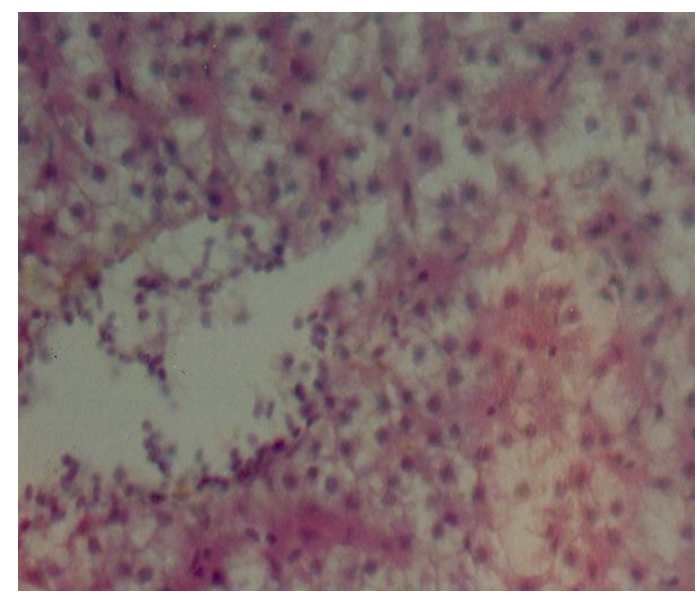

Fig. 4. Section of liver of $L$. rohita from treatment 4. Necrotic hepatocytes with huge empty spaces and some glycogen deposition are seen (H\&Ex420).
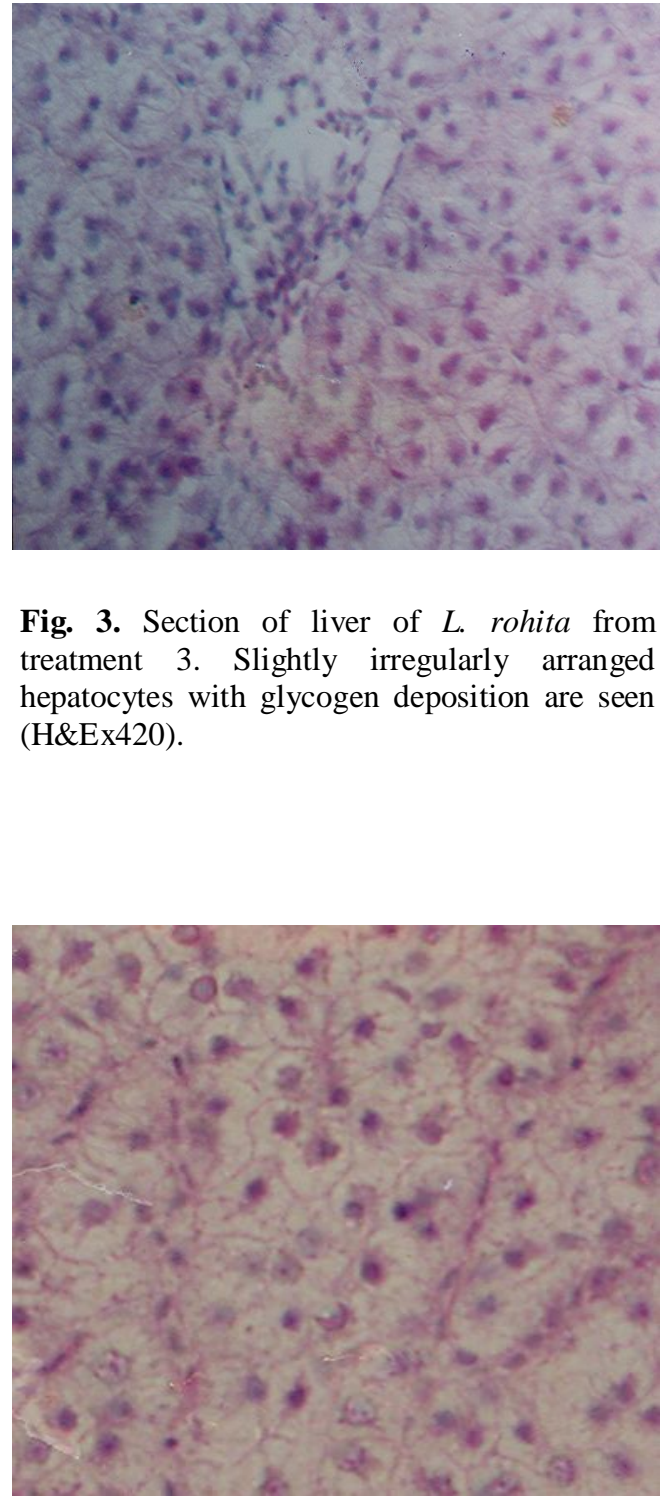

Fig. 3. Section of liver of $L$. rohita from treatment 3. Slightly irregularly arranged hepatocytes with glycogen deposition are seen (H\&Ex420).

Fig. 5. Section of liver of $L$. rohita from treatment 2 . Normally arranged hepatocytes with no glycogen and intercellular fat deposition (H\&Ex420). 


\section{Conclusions}

Soybean meal protein has one of the best amino acid profiles to meet the high protein requirement, although with some limitations. The results of the present study indicate that soybean meal can be a promising ingredient that could substitute fishmeal in the diet of L. rohita fry up to $50 \%$ without amino acid supplementation.

\section{Acknowledgements}

We are thankful to BAU-USDA-Soybean Project for providing fund to carryout the research work. The authors thank Dr. Lutfur Rahman, Professor, Department of Genetics and Plant Breeding, Bangladesh Agricultural University, Mymensingh for his assistance in conducting this research work.

\section{References}

Akand, A.M., Soeb, M., Hasan, M.R. and Kibria, M.G. 1991. Nutritional requirements of Indian major carps, Labeo rohita (Hamilton)-1. Effect of dietary protein on growth, food conversion and body composition. Agriculture International, 1: $35-43$.

Akhteruzzaman, Kh. 1999. The use of soybean meal as a fishmeal replacer in the diet for Indian major carp Labeo rohita (Hamliton) fingerlings. M.S. Thesis Department of Aquaculture, Bangladesh Agricultural University, Mymensingh. Bangladesh. 86 p.

Akiyama, D.M. 1989. Soybean meal utilization in fish feeds. Proc. People's Republic of China-Aquaculture and Feed Workshop, September 17-30. Singapore-Singapore American Soybean Association. 362-378 pp.

AOAC 1990. Official Methods of Analysis, $15^{\text {th }}$ edn., Association of Official Analytical Chemists, Washington, DC, USA, 1094 p.
APHA, 1980. Standard Methods for the examination of water and waste water, $15^{\text {th }}$ edn., American Public Health Association, Washington DC, USA, 1134 p.

Devi, C. Vijayaraghavan, S. and Srinivasulu, C. 1999. Effect of soybean meal (Glycine max) feeding on the biochemical composition of $L$. rohita fingerlings. Journal of Aquaculture in the Tropics, 14(2):181-185.

El-Sayed, A. F. M. 1999. Alternative dietary protein sources for farmed tilapia, Oreochromis spp. Aquaculture, 179(1-4): 149-168.

Fagbenro, O. A. 1998. Apparent digestibility of various legume seed meals in Nile tilapia diets. Aquaculture-International, 6(1): 8387.

Hasanuzzaman, A. F. M., Siddiqui, M. N. and Chisty M. A. H. 2009. Optimum replacement of fishmeal with soybean meal in diet for Macrobrachium rosenbergii (de Man 1879) cultured in low saline water. Turkish Journal of Fisheries and Aquatic Sciences, 9(1): 1722.

Hossain, M. A. and Jauncey. K. 1989. Nutritional evaluation of some Bangladeshi oil seed meals as partial substitutes for fishmeal in the diets of common carp, Cyprinus carpio L. Aquaculture Fish Management, 20: 225268.

Humason, G. L. 1979. Animal Tissue Techniques. W. H. Freeman and company, San Francisco, 611 p.

Khan, N., Ashraf, M., Qureshi, N. A., Sarker, P. K., Vandenberg, G. W. and Rasool, F. 2012. Effect of similar feeding regime on growth and body composition of Indian major carps (Catla catla, Cirrhinus mrigala and Labeo rohita) under mono and polyculture. African Journal of Biotechnology, 11(44): 10280-10290. 
Lim, C. and Dominy, W. 1991. Utilization of plant proteins by warm water fish. Proc. the Aquaculture Feed Processing and Nutrition Workshop, September, 19-25, 1991 Thailand and Indonesia, American Soybean-Association, 163-172 pp.

Nose, T. 1979. Summary report on the requirements for essential amino acids for carp. In: Finfish Nutrition and Fish feed Technology, (eds). J. E. Halver, and Tiews, K. Heenemann, Berlin, Germany, 145-156 pp.

O'keefe, T. 2003. Plant protein ingredients for aquaculture feeds: Use considerations and quality standards. Aquaculture Seminars, 24-28 July, 2003. Mymensingh-KhulnaDhaka, Bangladesh, 14 p.

Pongmaneerat, J. and Watanabe, T. 1993. Nutritional evaluation of soybean meal for rainbow trout and carp. Nippon Suisan Gakkaishi, 59(1): 157-163.

Priyadarshini, M., Manissery, J. K., Gangadhara, B., Rao, L. M. and Keshavanath, P. 2011. Growth responses of Catla catla (Actinopterygii: Cypriniformes: Cyprinidae) to soya and maize supplemented traditional feed mixture. Acta Ichthyological Et Piscatoria, 41(3): 159-164.

Robaina, L., Izquierdo, M. S., Moyano, F. J., Socorro, J., Vergara, J. M., Montero, D. and Fernandez-Palacios, H. 1995. Soybean and lupin seed meals as protein sources in diets for gilhead seabream (Sparus aurata): Nutritional and histological implication. Aquaculture, 130: 219-233
Saha, A. K. and Ray, A. K. 1998. Performance of rohu, Labeo rohita (Hamilton), fingerlings maintained on alternative feeding of plant and animal protein based diets. Acta Ichthyologica et Piscatoria. XXVIII, Fase. 1: 3-13.

Shiau, S. Y., Lin, S. F., Yu, S. L., Lin, A. L., and Kwok, C. C. 1990. Defatted or full-fat soybean meal as partial replacement for fishmeal in tilapia (Oreochromis niloticus x O. aureus) diets at low protein level. Aquaculture, 86(4): 401-407.

Shiau, S. Y., Lowk, C. C., Kwang, J. Y., Chen, C. M. and Lee, S. L. 1989. Replacement of fishmeal with soybean meal in male tilapia (Oreochromis niloticus x $O$. aureus) fingerling's diets at a Sub-optimal protein level. Journal of World Aquaculture Society, 20(4): 230-235.

Tacon A. G. J. 1993. Feed Ingredients for warmwater fish: Fishmeal and other Processed Feedstuffs. FAO Fisheries Circ., No. 856, FAO, Rome. Italy, 64 p.

Viola S., Mlokady, S., Rappaport, U. and Arieli, Y. 1982. Partial and complete replacement of fishmeal by soybean meal in feeds for intensive culture of carps. Aquaculture, 26: 223-226.

Wee, K. L. 1991. Extruded feeds- can they help reduce feed costs. Austasia-Aquaculture, 5(8): 31-33.

Wee, K. L. and Wang, S. S. 1987. Nutritive value of leucaena leaf meal in Pelleted feed for Nile tilapia. Aquaculture, 62: 97108 . 